\title{
Faktor-faktor yang Memengaruhi Permintaan Commuter Line Berdasarkan Karakteristik Fasilitas Park and Ride di Stasiun Sidoarjo
}

\author{
Annisa Rizky Nurkhariza dan Siti Nurlaela \\ Departemen Teknik Sipil, Institut Teknologi Sepuluh Nopember (ITS) \\ Corresponding Author: siti.nurlaela@postgrad.curtin.edu.au
}

\section{ARTIKEL INFO}

\section{Informasi Artikel}

Artikel masuk :

Artikel revisi :

Artikel diterima :

\begin{abstract}
ABSTRAK
Setiap harinya, terdapat 500.000 masyarakat Sidoarjo yang beraktivitas di Surabaya. Level of service (LOS) dari Jalan Ahmad Yani yang mencapai tingkat $\mathrm{E}$ menunjukkan tingginya penggunaan kendaraan pribadi dan kurangnya minat masyarakat dalam menggunakan transportasi massal. Salah satu upaya yang dapat dilakukan untuk meningfkatkan penggunaan transportasi massal adalah dengan penyediaan fasilitas park and ride. Penelitian ini bertujuan untuk mengetahui factor-faktor apa saja yang berpengaruh terhadap permintaan akan commuter line berdasarkan karakteristik fasilitas park and ride. Untuk mencapai tujuan tersebut, diperlukan empat sasaran penelitian, yaitu pemilihan stasiun berdasarkan indikator fasilitas park and ride dan tingkat penumpang tinggi sebagai studi kasus, menganalisis karakteristik fasilitas park and ride di stasiun terpilih, identifikasi karakteristik pengguna dan non-pengguna commuter line, dan identifikasi faktor-faktor yang memengaruhi permintaan commuter line berdasarkan karakteristik fasilitas park and ride. Hasil penelitian menunjukkan, dari 14 variabel independen, terdapat lima variabel yang berpengaruh secara signifikan, yaitu usia, maksud perjalanan, waktu, kemudahan mencapai lokasi, dan tingkat layanan angkutan.
\end{abstract}

\section{Kata Kunci}

Commuter Line, Park and Ride, Regresi Logistik Biner, Stasiun Sidoarjo. pada kenyataannya sejak diluncurkan tahun 2004 commuter line SuSi belum dapat menurunkan angka kemacetan [2].

Peningkatan penggunaan transportasi massal dapat dilakukan dengan penyediaan fasilitas-fasilitas penunjang, salah satunya adalah fasilitas park and ride [3]. Fasilitas park and ride dapat memberikan manfaat yang cukup besar terhadap sistem transportasi jika diimplementasikan bersamaan dengan perbaikan sistem transportasi yang sudah ada [4]. Fasilitas park and ride merupakan fasilitas parkir dimana pelaku pergerakan memarkirkan kendaraannya pada ruang parkir, kemudian beralih menggunakan transportasi massal [5].

Berdasarkan fakta-fakta diatas, perlu adanya penelitian terkait faktor-faktor apa saja yang memengaruhi permintaan commuter line berdasarkan karakteristik fasilitas park and ride. Faktor-faktor tersebut kemudian dapat diimplementasikan dan diharapkan dapat meningkatkan penggunaan commuter line SuSi.

\section{METODE PENELITIAN}

\section{A. Jenis dan Pendekatan Penelitian}

Pendekatan yang digunakan dalam penelitian ini adalah pendekatan positivistik, dimana fenomenanya dapat diklasifikasikan secara tetap, terukur, dan terdapat
$\mathrm{SuSi}$ juga diharapkan mampu mengurangi tingkat kemacetan di Surabaya sebesar $10 \%$ hingga $15 \%$, namun 
hubungan sebab akibat. Pengambilan sampel dalam penelitian ini juga harus representatif dan secara random [6]. Jenis penelitian ini adalah penelitian kuantitiatif karena menggunakan data angka dan diolah secara statistik dan matematis.

\section{B. Variabel Penelitian}

Dalam penelitian ini digunakan 17 variabel dan enam sub variabel yang terdiri dari aspek stasiun dan pengguna. Adapun untuk aspek stasiun terdiri dari indikator karaktersitik fasilitas park and ride dan tingkat penggunaan stasiun, sedangkan aspek pengguna terdiri dari karakteristik sosialdemografi dan karakteristik perjalanan. Indikator karakteristik fasilitas park and ride terdiri atas variabel kemudahan mencapai lokasi, ketersediaan ruang parkir, tingkat keamanan, dan tingkat kenyamanan, sedangkan indikator tingkat penggunaan stasiun terdiri atas variabel jumlah penumpang stasiun. Indikator karakteristik sosial ekonomi terdiri atas variabel usia, jenis kelamin, tingkat pendapatan, pekerjaan, dan tingkat kepemilikan kendaraan, sedangkan indikator karakteristik perjalanan terdiri atas asal perjalanan, jarak tempat tinggal dengan fasilitas park and ride, maksud perjalanan, waktu (waktu akses, waktu tunggu, dan waktu tempuh), biaya (biaya parkir, tarif commuter line, dan biaya kendaraan pribadi), jarak perjalanan, dan tingkat layanan angkutan. Untuk lebih jelasnya dapat dilihat pada Tabel 1 .

Tabel 1. Variabel Penelitian

\begin{tabular}{|c|c|c|c|}
\hline Aspek & Indikator & Variabel & Sub Variabel \\
\hline \multirow[t]{9}{*}{ Stasiun } & Karakteristik & Kemudahan mencapai & \\
\hline & Fasilitas Park & lokasi & \\
\hline & and Ride & Ketersediaan ruang & \\
\hline & & parkir & \\
\hline & & Tingkat keamanan & \\
\hline & & Tingkat kenyamanan & \\
\hline & Tingkat & Jumlah penumpang di & \\
\hline & Penggunaan & stasiun transit & \\
\hline & Stasiun & & \\
\hline \multirow[t]{23}{*}{ Pengguna } & Karakteristik & Usia & \\
\hline & sosial & Jenis kelamin & \\
\hline & ekonomi & Tingkat pendapatan & \\
\hline & & Pekerjaan & \\
\hline & & Tingkat kepemilikan & \\
\hline & & kendaraan & \\
\hline & Karakteristik & Asal perjalanan & \\
\hline & perjalanan & Jarak tempat tinggal & \\
\hline & & $\begin{array}{l}\text { dengan fasilitas park } \\
\text { and ride }\end{array}$ & \\
\hline & & Maksud perjalanan & \\
\hline & & Waktu & Waktu \\
\hline & & & tempuh \\
\hline & & & Waktu tunggu \\
\hline & & & Waktu akses \\
\hline & & Biaya & Biaya parkir \\
\hline & & & Tarif kereta \\
\hline & & & komuter \\
\hline & & & Biaya \\
\hline & & & kendaraan \\
\hline & & & pribadi \\
\hline & & Jarak perjalanan & \\
\hline & & Tingkat layanan & \\
\hline & & angkutan & \\
\hline
\end{tabular}

C. Pemilihan Stasiun Berdasarkan Indikator Fasilitas Park and Ride dan Tingkat Penumpang yang Tinggi Sebagai Studi Kasus

Untuk pemilihan stasiun dilakukan dengan analisis deskriptif terhadap indikator fasilitas park and ride dan tingkat penumpang yang tinggi. Adapun variabel yang termasuk ke dalam indikator fasilitas park and ride meliputi kemudahan mencapai lokasi fasilitas park and ride, ketersediaan ruang parkir, tingkat keamanan, dan tingkat kenyamanan. Data jumlah penumpang stasiun berasal dari data sekunder yang didapatkan dari PT. KAI DAOP VIII Jawa Timur, sedangkan data indikator fasilitas park and ride didapatkan dari hasil observasi lapangan. Setelah mendapatkan data karakteristik stasiun dan jumlah penumpang tiap stasiun, maka stasiun yang dipilih merupakan stasiun yang memiliki karakteristik fasilitas park and ride yang paling memadai dan jumlah penumpang tertinggi.

\section{Penentuan Catchment Area di Stasiun Terpilih}

Analisis catchment area di stasiun terpilih bertujuan untuk mengetahui radius pelayanan dari fasilitas park and ride yang terdapat di stasiun terpilih. Analisis ini dilakukan melalui pemetaan potensi penumpang dari kawasan sekitar stasiun dengan asumsi menggunakan kendaraan bermotor. Untuk mengetahui potensi penumpang commuter line dilakuan pengumpulan data melalui survei primer. Data yang diperlukan untuk analisis ini adalah data asal perjalanan dan jarak tempat tinggal dengan fasilitas park and ride. Pengumpulan data dilakukan melalui kuesioner yang dibagikan kepada pengguna commuter line di stasiun terpilih. Adapun hasil dari analisis ini adalah peta catchment area fasilitas park and ride di stasiun terpilih. Peta catchment area tersebut kemudian digunakan untuk menentukan responden dari non-pengguna commuter line.

E. Identifikasi Karakteristik Pengguna dan Nonpengguna Commuter Line di Stasiun Terpilih Studi Kasus

Identifikasi karakteristik pengguna dan non-pengguna fasilitas park and ride dilakukan dengan metode statistic deskriptif, uji t, dan ANOVA. Analisis ini bertujuan untuk mengetahui apakah terdapat perbedaan karakteristik antara pengguna dan non-pengguna commuter line berdasarkan indikator sosial ekonomi dan asal perjalanan. Adapun variabel yang dianalisis karakteristiknya meliputi, usia, jenis kelamin, pekerjaan, tingkat pendapatan, tingkat kepemilikan kendaraan, maksud perjalanan, waktu, biaya, dan jarak.

Pengumpulan data dilakukan kepada 138 responden yang merupakan pengguna dan non-pengguna commuter line di stasiun terpilih. Pengumpulan data untuk pengguna commuter line dilakukan di stasiun terpilih, sedangkan untuk non-pengguna commuter line dilakukan survei rumah tangga berdasarkan catchment area fasilitas park and ride.

F. Identifikasi Faktor - faktor yang Memengaruhi Permintaan Commuter Line Berdasarkan Karakteristik Fasilitas Park and Ride di Stasiun Terpilih

Identifikasi faktor-faktor yang memengaruhi permintaan commuter line berdasarkan karakteristik fasilitas park and ride bertujuan untuk mengetahui faktor apa saja yang memengaruhi permintaan commuter line di stasiun terpilih. Adapun variabel yang digunakan dalam analisis ini adalah semua variabel penelitian kecuali variabel tingkat penumpang stasiun, asal perjalanan, dan jarak tempat tinggal dengan fasilitas park and ride. Terdapat 14 variabel independen yang digunakan untuk menganalisis faktor-faktor yang memengaruhi 
permintaan commuter line. Metode analisis yang digunakan adalah regresi logistik biner dan software yang digunakan untuk analisis adalah Statistic Package for Social Science (SPSS).

\section{HASIL DAN DISKUSI}

A. Pemilihan Stasiun Berdasarkan Indikator Fasilitas Park and Ride dan Tingkat Penumpang yang Tinggi Sebagai Studi Kasus

Berdasarkan hasil observasi, Stasiun Sidoarjo memiliki skor yang tertinggi untuk karakteristik fasilitas park and ride dan jumlah penumpang. Kemudahan mencapai lokasi fasilitas park and ride di Stasiun Sidoarjo tergolong paling mudah karena dapat diakses oleh segala jenis kendaraan bermotor maupun tidak dan dapat diakses juga oleh pejalan kaki. Untuk ketersediaan ruang parkir juga tergolong paling memadai karena waktu yang digunakan untuk mencari parkir adalah kurang dari dua menit. Tingkat keamanan tergolong paling aman karena sudah terdapat karcis parkir, petugas keamanan, dan penerangan yang cukup. Namun, kamera pengawas hanya terdapat di dalam area stasiun, belum terdapat di area parkir. Untuk tingkat kenyamanan dapat dikatakan paling nyaman. Hal tersebut dapat dilihat dari tersedianya papan-papan informasi, ruang tunggu, dan toilet dengan kondisi yang baik. Untuk jumlah penumpang tertinggi juga terdapat di Stasiun Sidoarjo, yaitu sebesar 67.739 penumpang pertahun, jika dibandingkan dengan jumlah penumpang Stasiun Waru dan Stasiun Gedangan adalah 13.936 dan 21.994 penumpang.

\section{B. Penentuan Catchment Area di Stasiun Terpilih}

Berdasarkan hasil survei primer, diketahui bahwa dari 28 pengguna commuter line dan pengguna fasilitas park and ride, 23 responden diantaranya berasal dari dalam radius empat kilometer, sedangkan lima responden lainnya berasal dari luar radius empat kilometer dari Stasiun Sidoarjo. Jarak tempat tinggal responden dengan fasilitas park and ride Stasiun Sidoarjo terdekat adalah 0,6 kilometer, sedangkan jarak terjauh adalah sebesar 10,8 kilometer. Sehingga, peta catchment area fasilitas park and ride di Stasiun Sidoarjo dapat dilihat pada Gambar 1.

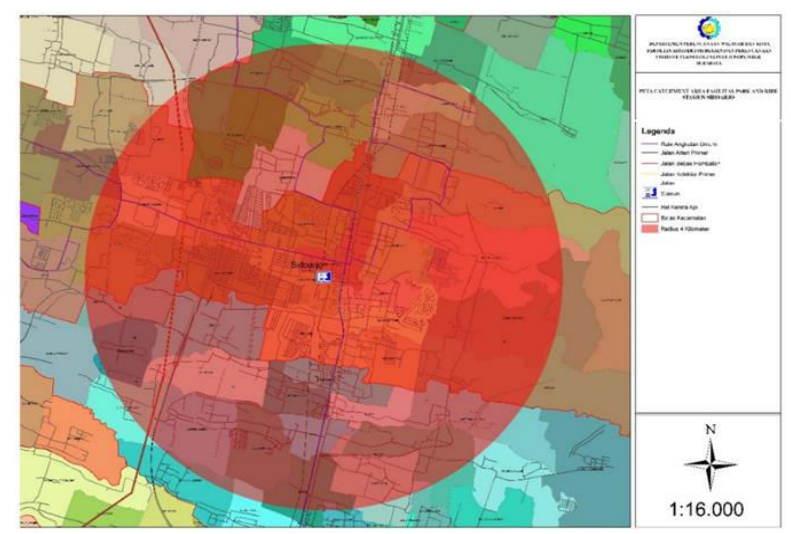

Gambar 1. Peta Catchment Area Fasilitas Park and Ride di Stasiun Sidoarjo.
C. Identifikasi Karakteristik Pengguna dan Nonpengguna Commuter Line di Stasiun Terpilih Studi Kasus

Berdasarkan hasil analisis uji t dan ANOVA dari 138 responden, dapat diketahui bahwa karakteristik sosial ekonomi dan perjalanan antara pengguna dan nonpengguna commuter line tidak terdapat perbedaan yang signifikan. Untuk lebih jelasnya adalah sebagai berikut.

1. Jenis kelamin

Jenis kelamin pengguna dan non-pengguna commuter line didominasi oleh wanita. Sebesar $79 \%$ responden pengguna commuter line merupakan wanita, serta $67 \%$ dari responden non-pengguna commuter line juga merupakan wanita.

2. Usia

Usia pengguna dan non-pengguna commuter line didominasi oleh kelompok umur 17-22 tahun.

3. Tingkat pendapatan

Secara keseluruhan tingkat pendapatan antara pengguna dan non-pengguna commuter line didominasi dengan tingkat pendapatan kurang dari Rp500.000.

\section{Pekerjaan}

Pekerjaan pengguna dan non-pengguna commuter line didominasi oleh pelajar/mahasiswa.

5. Tingkat kepemilikan kendaraan pribadi

Tingkat kepemilikan kendaraan pribadi pengguna dan non-pengguna commuter line didominasi oleh tingkat kepemilikan kendaraan pribadi 1 .

6. Maksud perjalanan

Berdasarkan hasil observasi, maksud perjalanan pengguna dan non-pengguna commuter line didominasi dengan maksud perjalanan kuliah.

7. Waktu

Untuk pengguna commuter line, waktu terbagi atas waktu akses, waktu tunggu, dan wakt tempuh. Untuk itu, waktu perjalanan pengguna commuter line akan lebih lama jika dibandingkan dengan non-pengguna commuter line. Waktu pengguna commuter line rata-rata adalah 7690 menit, sedangkan waktu non-pengguna commuter line adalah 45-60 menit.

8. Biaya

Biaya yang dikeluarkan oleh pengguna commuter line meliputi biaya akses, biaya parkir, dan tarif kereta, sedangkan untuk non-pengguna commuter line biaya yang dimaksud adalah biaya bahan bakar. Untuk pengguna commuter line, rata-rata biaya yang dikelarkan adalah Rp20.001-Rp30.000, sedangkan untuk nonpengguna commuter line rata-rata biaya yang dikeluarkan adalah Rp10.000-Rp20.000.

9. Jarak

Berdasarkan hasil observasi, tidak terdapat perbedaan yang signifikan untuk jarak perjalanan antara pengguna dan non-pengguna commuter line. Hasil observasi menunjukkan responden menempuh jarak perjalanan 25,1-30 km.

Analisis uji t digunakan untuk menganalisis variabel non kategorik, seperti usia $\left(\mathrm{X}_{2}\right)$, tingkat kepemilikan kendaraan $\left(\mathrm{X}_{5}\right)$, waktu $\left(\mathrm{X}_{7}\right)$, biaya $\left(\mathrm{X}_{8}\right)$, dan jarak $\left(\mathrm{X}_{9}\right)$. Analisis uji t terdiri atas dua tahap, yaitu uji varian dan uji t. Berdasarkan hasil analisis uji varian, dapat diketahui bahwa varian usia, tingkat kepemilikan kendaraan, waktu, dan biaya antara pengguna dan nonpengguna commuter line adalah berbeda, sedangkan varian jarak antara pengguna dan non-pengguna 
commuter line adalah sama. Berdasarkan hasil nilai thitung untuk variabel usia, tingkat kepemilikan kendaraan, waktu, biaya, dan jarak, dapat diketahui bahwa tidak terdapat perbedaan rata-rata antara pengguna dan non-pengguna commuter line. Adapun hasil dari analisis uji t untuk variabel-variabel di atas dapat dilihat pada Tabel 2: 
Tabel 2. Hasil Uji T

\begin{tabular}{|c|c|c|c|}
\hline $\mathrm{No}$ & Variabel & Uji Varian & Uji $t$ \\
\hline 1 & Usia & $\begin{array}{l}\text { Fhitung }(19,301)> \\
\text { Ftabel }(1,475), \\
\text { sehingga } \mathrm{H}_{0} \text { ditolak. } \\
\text { Artinya, varian usia } \\
\text { pengguna } \neq \text { varian } \\
\text { usia non-pengguna. }\end{array}$ & $\begin{array}{l}\text { Thitung }(-2,262)< \\
\text { Ttabel }(1,681), \\
\text { sehingga } \mathrm{H}_{0} \text { gagal } \\
\text { tolak. Artinya, rata- } \\
\text { rata usia pengguna = } \\
\text { rata-rata usia non- } \\
\text { pengguna. }\end{array}$ \\
\hline 2 & $\begin{array}{l}\text { Tingkat } \\
\text { kepemilikan } \\
\text { kendaraan }\end{array}$ & $\begin{array}{l}\text { Fhitung }(1,562)> \\
\text { Ftabel }(1,403) \text {, } \\
\text { sehingga } \mathrm{H}_{0} \text { ditolak. } \\
\text { Artinya, varian } \\
\text { tingkat kepemilikan } \\
\text { kendaraan pengguna } \\
\text { \# varian tingkat } \\
\text { kepemilikan } \\
\text { kendaraan non- } \\
\text { pengguna. }\end{array}$ & $\begin{array}{l}\text { Thitung }(1,578)< \\
\text { Ttabel }(1,682) \text {, } \\
\text { sehingga } \mathrm{H}_{0} \text { gagal } \\
\text { tolak. Artinya, rata- } \\
\text { rata tingkat } \\
\text { kepemilikan } \\
\text { kendaraan pengguna } \\
=\text { rata-rata tingkat } \\
\text { kepemilikan } \\
\text { kendaraan non- } \\
\text { pengguna. }\end{array}$ \\
\hline 3 & Waktu & $\begin{array}{l}\text { Fhitung }(9,912)> \\
\text { Ftabel }(1,308) \text {, } \\
\text { sehingga } \mathrm{H}_{0} \text { ditolak. } \\
\text { Artinya, varian } \\
\text { waktu tempuh } \\
\text { pengguna } \neq \text { varian } \\
\text { waktu tempuh non- } \\
\text { pengguna. }\end{array}$ & $\begin{array}{l}\text { Thitung }(-7,406)< \\
\text { Ttabel }(1,665) \text {, } \\
\text { sehingga } \mathrm{H}_{0} \text { gagal } \\
\text { tolak. Artinya, rata- } \\
\text { rata waktu tempuh } \\
\text { pengguna = rata-rata } \\
\text { waktu tempuh non- } \\
\text { pengguna. }\end{array}$ \\
\hline 4 & Biaya & $\begin{array}{l}\text { Fhitung }(14,274)> \\
\text { Ftabel }(1,278), \\
\text { sehingga } \mathrm{H}_{0} \text { ditolak. } \\
\text { Artinya, varian biaya } \\
\text { perjalanan pengguna } \\
\neq \text { varian biaya } \\
\text { perjalanan non- } \\
\text { pengguna. }\end{array}$ & $\begin{array}{l}\text { Thitung }(-1,584)< \\
\text { Ttabel }(1,662), \\
\text { sehingga } \mathrm{H}_{0} \text { gagal } \\
\text { tolak. Artinya, rata- } \\
\text { rata biaya perjalanan } \\
\text { pengguna = rata -rata } \\
\text { biaya perjalanan non- } \\
\text { pengguna. }\end{array}$ \\
\hline 5 & Jarak & $\begin{array}{l}\text { Fhitung }(0,057)< \\
\text { Ftabel }(1,419), \\
\text { sehingga } \mathrm{H}_{0} \\
\text { diterima. Artinya, } \\
\text { varian jarak } \\
\text { perjalanan pengguna } \\
\text { = varian jarak } \\
\text { perjalanan non- } \\
\text { pengguna. }\end{array}$ & $\begin{array}{l}\text { Thitung }(-0,503)< \\
\text { Ttabel }(1,656), \\
\text { sehingga } \mathrm{H}_{0} \text { gagal } \\
\text { tolak. Artinya, rata- } \\
\text { rata jarak perjalanan } \\
\text { pengguna = rata -rata } \\
\text { jarak perjalanan non- } \\
\text { pengguna }\end{array}$ \\
\hline
\end{tabular}

Tabel 3. Hasil Uji ANOVA

\begin{tabular}{|c|c|c|}
\hline No & Variabel & Uji ANOVA \\
\hline 1 & $\begin{array}{l}\text { Jenis } \\
\text { kelamin }\end{array}$ & $\begin{array}{l}\text { Nilai sig pada tabel ANOVA }(0,136)>\alpha(0,1) \text {, } \\
\text { sehingga } \mathrm{H}_{0} \text { gagal tolak. Artinya, rata-rata jenis } \\
\text { kelamin pengguna = rata-rata jenis kelamin non- } \\
\text { pengguna. }\end{array}$ \\
\hline 2 & $\begin{array}{l}\text { Tingkat } \\
\text { pendapatan }\end{array}$ & $\begin{array}{l}\text { Nilai sig pada tabel ANOVA }(0,639)>\alpha(0,1) \text {, } \\
\text { sehingga } \mathrm{H}_{0} \text { gagal tolak. Artinya, rata-rata } \\
\text { tingkat pendapatan pengguna = rata-rata tingkat } \\
\text { pendapatan non-pengguna. }\end{array}$ \\
\hline 3 & Pekerjaan & $\begin{array}{l}\text { Nilai sig pada tabel ANOVA }(0,065)<\alpha(0,1) \text {, } \\
\text { sehingga } \mathrm{H}_{0} \text { ditolak. Artinya, rata-rata pekerjaan } \\
\text { pengguna } \neq \text { rata-rata pekerjaan non-pengguna. }\end{array}$ \\
\hline 4 & $\begin{array}{l}\text { Maksud } \\
\text { perjalanan }\end{array}$ & $\begin{array}{l}\text { Nilai sig pada tabel ANOVA }(0,274)>\alpha(0,1) \text {, } \\
\text { sehingga } \mathrm{H}_{0} \text { gagal tolak. Artinya, rata-rata } \\
\text { maksud perjalanan pengguna = rata-rata maksud } \\
\text { perjalanan non-pengguna. }\end{array}$ \\
\hline
\end{tabular}

Analisis uji ANOVA digunakan untuk variabel kategorik, yang meliputi, jenis kelamin $\left(\mathrm{X}_{1}\right)$, tingkat pendapatan $\left(\mathrm{X}_{3}\right)$, pekerjaan $\left(\mathrm{X}_{4}\right)$, dan maksud perjalanan $\left(\mathrm{X}_{6}\right)$. Berdasarkan hasil uji ANOVA, dapat diketahui bahwa rata-rata jenis kelamin, tingkat pendapatan, dan maksud perjalanan untuk pengguna dan non-pengguna commuter line adalah sama, sedangkan rata-rata pekerjaan antara pengguna dan non-pengguna commuter line adalah berbeda. Dari hasil tersebut dapat diketahui bahwa terdapat perbedaan yang signifikan untuk variabel pekerjaan antara pengguna dan non-pengguna commuter line. Untuk jenis kelamin, tingkat pendapatan, dan maksud perjalanan, tidak terdapat perbedaan yang signifikan antara pengguna dan non-pengguna commuter line. Untuk lebih jelasnya dapat dilihat pada Tabel 3.

D. Identifikasi Faktor-faktor yang Memengaruhi Permintaan Commuter Line Berdasarkan Karakteristik Fasilitas Park and Ride di Stasiun Terpilih

Pada tahap ini akan dibahas mengenai faktor-faktor yang memengaruhi permintaan commuter line berdasarkan karakteristik fasilitas park and ride. Variabel yang digunakan dalam analisis ini terdiri atas variabel dependen dan independen. Untuk lebih jelasnya dapat dilihat pada Tabel 4.

Tabel 4. Variabel Analisis

\begin{tabular}{|c|c|c|}
\hline Jenis Variabel & Variabel & Kategori \\
\hline Dependen & $\begin{array}{c}\text { Pilihan penggunaan } \\
\text { fasilitas park and ride }(\mathrm{Y})\end{array}$ & $\begin{array}{l}0=\text { non-pengguna } \\
\text { commuter line } \\
1=\text { pengguna } \\
\text { commuter line }\end{array}$ \\
\hline \multirow[t]{14}{*}{ Independen } & Jenis Kelamin $\left(\mathrm{X}_{1}\right)$ & $\begin{array}{l}0=\text { laki-laki } \\
1=\text { perempuan }\end{array}$ \\
\hline & Usia $\left(\mathrm{X}_{2}\right)$ & Data metrik \\
\hline & Tingkat pendapatan $\left(\mathrm{X}_{3}\right)$ & $\begin{array}{l}0=<\operatorname{Rp} 500.000 \\
1=\operatorname{Rp} 500.000- \\
\text { Rp1.000.000 } \\
2=\text { Rp1.000.001- } \\
\text { Rp2.500.000 } \\
3=\text { Rp2.500.001- } \\
\text { Rp5.000.000 } \\
4=>\operatorname{Rp} 5.000 .000\end{array}$ \\
\hline & Pekerjaan $\left(\mathrm{X}_{4}\right)$ & $\begin{array}{l}0=\text { Selain } \\
\text { Pelajar/Mahasiswa } \\
1 \text { = Pelajar/Mahasiswa }\end{array}$ \\
\hline & $\begin{array}{l}\text { Tingkat kepemilikan } \\
\text { kendaraan }\left(\mathrm{X}_{5}\right)\end{array}$ & Data metrik \\
\hline & Maksud perjalanan $\left(\mathrm{X}_{6}\right)$ & $\begin{array}{l}0=\text { Selain } \\
\text { Sekolah/Kuliah } \\
1=\text { Sekolah/Kuliah }\end{array}$ \\
\hline & Waktu $\left(\mathrm{X}_{7}\right)$ & Data metrik \\
\hline & Biaya $\left(\mathrm{X}_{8}\right)$ & Data metrik \\
\hline & $\operatorname{Jarak}\left(\mathrm{X}_{9}\right)$ & Data metrik \\
\hline & $\begin{array}{c}\text { Kemudahan mencapai } \\
\text { lokasi }\left(\mathrm{X}_{10}\right)\end{array}$ & $\begin{array}{l}0=\text { Sangat Sulit } \\
1=\text { Cukup Mudah } \\
2=\text { Sangat Mudah }\end{array}$ \\
\hline & $\begin{array}{l}\text { Ketersediaan ruang parkir } \\
\qquad\left(\mathrm{X}_{11}\right)\end{array}$ & $\begin{array}{l}0=\text { Tidak Memadai } \\
1=\text { Cukup Memadai } \\
2=\text { Sangat Memadai }\end{array}$ \\
\hline & Tingkat keamanan $\left(\mathrm{X}_{12}\right)$ & $\begin{array}{l}0=\text { Tidak Aman } \\
1=\text { Cukup Aman } \\
2=\text { Sangat Aman }\end{array}$ \\
\hline & Tingkat kenyamanan $\left(\mathrm{X}_{13}\right)$ & $\begin{array}{l}0=\text { Tidak Nyaman } \\
1=\text { Cukup Nyaman } \\
2=\text { Sangat Nyaman }\end{array}$ \\
\hline & $\begin{array}{l}\text { Tingkat layanan angkutan } \\
\qquad\left(\mathrm{X}_{14}\right)\end{array}$ & $\begin{array}{l}0=\text { Tidak Baik } \\
1=\text { Cukup Baik } \\
2=\text { Sangat Baik }\end{array}$ \\
\hline
\end{tabular}

Untuk melihat apakah model yang didapatkan layak atau tidak, maka perlu dilakukan beberapa tes, seperti uji 
Hosmer and Lemeshow's Goodness of Fit, Omnibus Test of Model Coefficient, dan nilai koefisien determinasi, selain itu juga dilihat dari nilai ketepatan klasifikasinya. Untuk lebih jelasnya dapat dilihat pada Tabel 5.

Tabel 5. Uji Kelayakan Model

\begin{tabular}{|c|c|c|c|}
\hline $\mathrm{No}$ & Tes & Hasil Analisis & Keterangan \\
\hline 1 & $\begin{array}{l}\text { Hosmer and } \\
\text { Lemeshow's } \\
\text { Goodness of } \\
\text { Fit }\end{array}$ & $\begin{array}{l}\text { Nilai yang } \\
\text { didapatkan } \\
\text { adalah } 0,681> \\
0,1(\alpha)\end{array}$ & $\begin{array}{l}\text { Model mampu memprediksi } \\
\text { nilai observasinya atau dapat } \\
\text { dikatakan model dapat } \\
\text { diterima karena cocok } \\
\text { dengan data observasinya. }\end{array}$ \\
\hline 2 & $\begin{array}{l}\text { Omnibus } \\
\text { Test of } \\
\text { Model } \\
\text { Coefficient }\end{array}$ & $\begin{array}{l}\text { Nilai yang } \\
\text { didapatkan } \\
\text { adalah } 0,0< \\
0,1(\alpha)\end{array}$ & $\begin{array}{l}\text { Variabel independen } \\
\text { berpengaruh terhadap } \\
\text { variabel dependen }\end{array}$ \\
\hline 3 & $\begin{array}{l}\text { Koefisien } \\
\text { Determinasi }\end{array}$ & $\begin{array}{l}\text { Nilai yang } \\
\text { didapatkan } \\
\text { adalah } 0,437\end{array}$ & $\begin{array}{l}\text { Variabel independen mampu } \\
\text { menjelaskan variasi variabel } \\
\text { dependen sebesar } 43,7 \% \text {, } \\
\text { sedangkan sisanya dijelaskan } \\
\text { oleh variabel lain. }\end{array}$ \\
\hline 4 & $\begin{array}{l}\text { Ketepatan } \\
\text { Klasifikasi }\end{array}$ & $\begin{array}{l}\text { Nilai yang } \\
\text { didapatkan } \\
\text { adalah } 81,9\end{array}$ & $\begin{array}{l}\text { Ketepatan model adalag } \\
81,9 \% \text { atau dapat dikatakan } \\
\text { dari } 138 \text { observasi, terdapat } \\
113 \text { observasi dengan } \\
\text { pengklasifikasian yang tepat }\end{array}$ \\
\hline
\end{tabular}

Berdasarkan hasil analisis diatas, maka model dapat dinyatakan layak karena model lulus uji kelayakan Hosmer and Lemeshow's Goodness of Fit, Omnimbus Test of Model Coefficient, koefisien determinasi, dan ketepatak klasifikasi. Model dianggap mampu memprediksi nilai observasinya, selain itu juga variabel independen yang digunakan berpengaruh terhadap variabel dependennya dan dapat menjelaskan variasi variabel dependen sebesar 43,7\%. Ketepatan klasifikasi data observasi yang terdapat di model juga cukup tinggi yaitu sebesar $81,9 \%$. Setelah dilakukan iterasi sebanyak tiga kali, maka model yang terbentuk dapat dilihat pada Tabel 6.

Tabel 6. Hasil Analisis Regresi Logit Biner Variables in the Equation

\begin{tabular}{|c|c|c|c|c|c|c|c|c|c|}
\hline \multicolumn{10}{|c|}{ Variables in the Equation } \\
\hline & & \multirow[b]{2}{*}{$B$} & \multirow[b]{2}{*}{ SE. } & \multirow[b]{2}{*}{ Wald } & \multirow[b]{2}{*}{ dif } & \multirow[b]{2}{*}{ Sig. } & \multirow[b]{2}{*}{$\operatorname{Exp}(B)$} & \multicolumn{2}{|c|}{$90 \%$ C.l.for EXP(B) } \\
\hline & & & & & & & & Lower & Unper \\
\hline \multirow[t]{6}{*}{ Step $1^{3}$} & Usia & .099 & .042 & 5.454 & 1 & .020 & 1.104 & 1.030 & 1.184 \\
\hline & Maksud & 1.782 & .893 & 3.983 & 1 & .046 & 5.941 & 1.368 & 25.802 \\
\hline & Waktu & .066 & .017 & 15.588 & 1 & .000 & 1.068 & 1.039 & 1.098 \\
\hline & Kemudahan & 1.402 & .578 & 5.892 & 1 & .015 & 4.065 & 1.572 & 10.515 \\
\hline & Tk_layanan & 1.512 & .720 & 4.408 & 1 & .036 & 4.534 & 1.387 & 14.820 \\
\hline & Constant & -13.681 & 2.865 & 22.799 & 1 & .000 & .000 & & \\
\hline
\end{tabular}

Berdasarkan hasil analisis, dari 14 variabel independen, terdapat lima variabel yang memengaruhi permintaan commuter line berdasarkan karakterisrik fasilitas park and ride. Variabel-variabel yang memiliki nilai Sig. < 0,1 , secara signifikan memengaruhi variabel dependen. Adapun variabel independen yang secara signifikan berpengaruh terhadap variabel dependen meliputi usia $\left(\mathrm{X}_{2}\right)$, maksud perjalanan $\left(\mathrm{X}_{6}\right)$, waktu $\left(\mathrm{X}_{7}\right)$, kemudahan mecapai lokasi $\left(\mathrm{X}_{10}\right)$ dan tingkat layanan angkutan $\left(\mathrm{X}_{14}\right)$.

Besarnya pengaruh yang diberikan oleh variabel independen terhadap variabel dependen dapat dilihat dari nilai Odds Ratio (OR) atau $\operatorname{Exp}(\mathrm{B})$.
Dari lima variabel yang berpengaruh signifikan, variabel maksud perjalanan merupakan variabel dengan tingkat pengaruh paling tinggi, yaitu sebesar 5,491. Sedangkan, untuk variabel dengan tingkat pengaruh paling rendah adalah variabel waktu, yaitu sebesar 1,068. Adapun persamaan model yang dihasilkan dari penelitian ini adalah:

$$
\begin{aligned}
\ln \left(\frac{p}{1-p}\right)=- & 13,681+0,099\left(\mathrm{X}_{2}\right)+1,782\left(\mathrm{X}_{6}\right)+0,066\left(\mathrm{X}_{7}\right) \\
& +1,402\left(\mathrm{X}_{10}\right)+1,512\left(\mathrm{X}_{14}\right)
\end{aligned}
$$

\section{KESIMPULAN}

Pada penelitian ini, penulis bertujuan untuk mengetahui faktor-faktor yang memengaruhi permintaan commuter line berdasarkan karakteristik fasilitas park and ride. Adapun kesimpulan dari penelitian ini adalah sebagai berikut.

1. Stasiun Sidoarjo merupakan stasiun dengan jumlah penumpang tertinggi dan karakteristik fasilitas park and ride paling memadai, bila dibandingkan dengan Stasiun Waru dan Stasiun Gedangan.

2. Catchment area dari fasilitas park and ride di Stasiun Sidoarjo adalah radius empat kilometer dari lokasi stasiun.

3. Berdasarkan hasil analisis, untuk variabel usia, jenis kelamin, tingkat pendapatan, tingkat kepemilikan kendaraan, waktu, maksud perjalanan, biaya, dan jarak, dapat diketahui bahwa tidak terdapat perbedaan yang signifikan antara pengguna dan non-pengguna commuter line. Untuk variabel pekerjaan, terdapat perbedaan yang siginifikan antara pengguna dan nonpengguna commuter line.

4. Hasil analisis menunjukkan, dari 14 variabel independen yang dimasukkan, terdapat lima variabel yang berpengaruh secara signifikan terhadap permintaan commuter line. Adapun kelima variabel tersebut meliputi variabel usia, maksud perjalanan, waktu, kemudahan mencapai lokasi, dan tingkat layanan angkutan.

\section{DAFTAR PUSTAKA}

[1] A. M. Pratama, "Analisis Faktor-Faktor Yang Mendorong Seseorang Untuk Melakukan Migrasi Ulang-Alik (Studi Kasus Pada Migran Kota Malang Yang Melakukan Migrasi Ulang-Alik Ke Surabaya Dengan Menggunakan Transportasi Bus)," J. Ilm. Mhs. FEB, vol. 1, no. 2, 2012.

[2] Surwadi, "Problematika Kemacetan Transportasi Umum di Kota Surabaya." Surabaya, 2010.

[3] D. F. Anisa, "Analisis Potensi Permintaan Fasilitas Park and Ride di Jalur Layanan KRL Jabodetabek,” Depok, 2014.

[4] Florida Departement of Transportation, "State Park and Ride Guide," Florida, 2012

[5] C. A. O'Flaherty, Transport planning and traffic engineering. Arnold, 1997.

[6] N. Hayati, "Pemilihan Metode yang Tepat dalam Penelitian (Metode Kualitatif dan Metode Kuantitatif)," J. Tarb. Al-Awlad, vol. IV, no. 1, pp. 345-357, 2015. 